\title{
Lutetium Lu 177 PP-F11N
}

National Cancer Institute

\section{Source}

National Cancer Institute. Lutetium Lu 177 PP-F11N. NCI Thesaurus. Code C114499.

A radioconjug ate composed of PP-F11N, a gastrin analog, conjug ated to the beta-

emitting radioisotope lutetium Lu 177, with potential antineoplastic activity and potential use as an imaging agent for scintigraphy. Following intravenous administration, the PP-

F11N moiety binds to the cholecystokinin-2 (CCK-2) receptor. Subsequently, the CCK-2 receptor-expressing tumor cells can be visualized scintigraphically. In addition, the radioisotope moiety delivers a cytotoxic dose of beta radiation to CCK-2 receptorexpressing tumor cells. CCK-2 receptors are expressed on a variety of tumor cell types. 